\title{
Fiktiva fall - fast inte som förr: faktoriella surveymetoden i högre utbildning
}

Lis a Wallander

Socialhögskolan, Lunds universitet

\begin{abstract}
Syftet med artikeln är att introducera och demonstrera ett pedagogiskt verktyg baserat på användningen av fiktiva fall (vinjetter) konstruerade enligt den experimentella faktoriella surveymetodens principer. Dessa vinjetter är - till skillnad från traditionella "case" eller "fallbeskrivningar" - helt igenom kvantitativa, i betydelsen att de kan analyseras i termer av ett antal variabler (dimensioner) och variabelvärden (nivåer). I korthet består kärnan i det pedagogiska verktyget $i$ att man låter studenter bedöma ett stort antal vinjetter, varpå man gör statistiska analyser separat för varje students vinjettbedömningar och låter resultaten av dessa ingå i en bedömningsprofil, vilken används som grund för systematisk reflektion och diskussion. Utöver de fördelar som finns med allt slags fallbaserat lärande, kan detta verktyg användas för att identifiera bedömningsmönster som studenterna själva är omedvetna om. Detta genererar tillfällen för reflektion kring det potentiella inflytandet av stereotypt tänkande $i$ bedömningar, och kring innehållet $i$ studenternas "tysta kunskap" på området för bedömningen. Det aktuella pedagogiska verktyget har utvecklats inom ramen för undervisning om professionella bedömningar, men kan användas i alla tänkbara universitetsoch högskolekurser där det finns intresse för att analysera, reflektera över och diskutera bedömningar (jfr uppfattningar, attityder, värderingar).
\end{abstract}

\section{INLEDNING: ETTT NYTT SLAGS FIKTIVA FALL I HÖGRE UTBILDNING}

Användningen av fiktiva fall som pedagogiskt verktyg i högre utbildning har över hundra år på nacken. Redan i slutet på 1800-talet och i början på 1900talet introducerades så kallad "case-method teaching" (jfr casemetodik) på Harvard Law och Business Schools (Lynn, 1999) ${ }^{1}$. Därefter har casemetodik exporterats till flertalet professionsutbildningar, som exempelvis högre 
utbildning i medicin, socialt arbete, omvårdnad och lärande/undervisning (för en översikt, se Milner \& Wolfer, 2014). Inom mitt eget fält - socialt arbete har det under senare år publicerats ett flertal artiklar på detta tema (t.ex. Cossom, 1991; Jones, 2003; Austin \& Packard, 2009; Milner \& Wolfer, 2014). I dessa artiklar görs gällande att casemetodik, vilket genomgående beskrivs som en undervisningsform som ger studenten tillfälle att stå i centrum och delta aktivt i sitt lärande (t.ex. Milner \& Wolfer, 2014), har ett stort antal fördelar. Bland dessa nämns möjligheten att träna på att 1) identifiera praktikrelevanta problem, 2) definiera begrepp, 3) utveckla kriterier för beslutsfattande, 4) lösa problem, 5) identifiera relevant kunskap för olika typer av praktikspecifika situationer och 6) tillämpa teoretisk kunskap på praktiska problem. Andra fördelar som betonas är att studenterna ges tillfälle att 7) konfrontera sina egna åsikter/antaganden vilka ibland kan tänkas involvera tidigare icke-reflekterade stereotyper kopplade till klass, kön och etnicitet, samtidigt som de 8) tränas i att hantera och respektera avvikande åsikter. Sist men inte minst antas casemetodik kunna stärka 9) studenternas motivation, 10) deras kreativitet och 11) kritiska tänkande samt 12) deras förmåga att verbalt kommunicera och rättfärdiga sina ståndpunkter (Jones, 2003; Austin \& Packard, 2009; Milner \& Wolfer, 2014; för en genomgång av resultat från utvärderingar av fallbaserat lärande, se Jones (2003) och Milner \& Wolfer (2014)).

Svensk litteratur på området uppvisar varierande terminologi. Ibland beskrivs de fiktiva fallen med hjälp av den engelska termen "case" (t.ex. Tärnvik, 2004), och andra gånger talar man om fallbeskrivningar (t.ex. Lindström, 2000) eller vinjetter (t.ex. Stiwne, 2009). I den här artikeln används termen vinjetter, vilka definieras som fiktiva beskrivningar av "en person, en situation eller ett skeende som försetts med karakteristika som forskaren[/läraren] kommit fram till är viktiga och avgörande i en val- eller bedömningssituation" (Jergeby, 1999: 12).

Syftet med föreliggande artikel är att introducera och demonstrera ett pedagogiskt verktyg som innefattar en mycket ovanlig typ av vinjett - en vinjett konstruerad enligt den experimentella faktoriella surveymetodens principer ([FSM]; jfr "the factorial survey approach"; Rossi, 1979; Rossi \& Nock, 1982; Wallander, 2009; Auspurg \& Hinz, 2015). Ursprungligen är faktoriella surveymetoden en forskningsmetod för storskaliga (främst sociologiska) projekt, i vilka man har för avsikt att beskriva och förklara bedömningar av något slag (jfr föreställningar, attityder). Det verktyg som beskrivs nedan utgör så vitt jag vet det första försöket någonsin att använda FSM-vinjetter $i$ undervisningssammanhang. Det främsta särdraget hos dessa vinjetter är att de är "kvantitativa" i den meningen att de kan analyseras i termer av ett antal variabler (dimensioner) och dess värden (nivåer). De vinjetter som används som exempel nedan skildrar personer som brukar alkohol eller narkotika, och som beskrivs utifrån ett flertal dimensioner 
och dimensionsnivåer, som t.ex. ålder (ung), kön (kvinna), bruksmedel (cannabis), osv.

Faktoriella surveymetoden som pedagogiskt verktyg [FSM-verktyget] innefattar en kärnövning - i tre steg - som kan tillämpas flexibelt och byggas ut efter behov. Inom ramen för kärnövningen får samtliga studenter (1) individuellt bedöma ett stort antal mycket korta varierande vinjetter. (2) Därefter analyseras varje students bedömningar separat med hjälp av statistisk analys. (3) Resultaten av analyserna, vilka åskådliggör studenternas individuella bedömningsgrunder, används sedan som underlag för diskussion i smågrupper och/eller i storgrupp. Övningen kan potentiellt inbegripa träning av de allra flesta av de kunskaper och förmågor som brukar nämnas i förbindelse med casemetodik (se ovan), men har också pedagogiska fördelar som är unika för just det här verktyget. Dessa grundas i verktygets experimentella konstruktion, och innefattar bland annat möjligheten att noggrant dissekera bedömningsgrunderna och analysera dem i termer av kausala samband mellan de dimensioner som är inbakade i vinjetterna och varje deltagares bedömningar. Dessutom är det möjligt att upptäcka individuella bedömningsmönster som studenterna själva är omedvetna om, vilket ger goda möjligheter för reflektion över det potentiella inflytandet av stereotypt tänkande i bedömningar, och över innehållet i studenternas "tysta kunskap" på området för bedömningen (jfr Wallander, 2012; Wallander \& Molander, 2016).

FSM-verktyget har utvecklats sedan 2010, och olika varianter har prövats och använts i undervisning om professionella bedömningar på socionomprogram och äldrepedagogprogram, samt i undervisning om statistiska analysmetoder på mastersprogram i kriminologi och socialt arbete. Det har även brukats i ett forsknings- och utvecklingsprojekt med praktiserande socialarbetare, poliser och åklagare (Wallander \& Laanemets, 2017) och har regelbundet använts vid utbildningsdagar med praktiserande socialarbetare. Som nämnts ovan är FSM-verktyget mycket flexibelt, och kan anpassas för att öva en mängd olika kunskaper och förmågor. I skrivande stund har det exempelvis använts specifikt för att öva argumentation och argumentationsanalys (Wallander \& Molander, 2016) och för att träna på grundläggande och avancerad statistisk analys. I föreliggande artikels avslutande del förs en diskussion om vilka olika lärandemoment som ingår (och som potentiellt kan ingå) i övningar baserade på det aktuella verktyget. Eftersom verktygets användningsområden är så många, och eftersom några av dessa avhandlas på annan plats, kommer utrymmet i den aktuella artikeln att brukas till att noggrant beskriva de mer tekniska aspekterna av FSMverktyget. Dessa inbegriper konstruktionen av verketyget, vilken sker i tre steg: 1) att bestämma vinjettdesignen, 2) att dra ett urval av vinjetter och, 3) att färdigställa vinjetterna; samt genomförandet av kärnövningen, vilket också sker i tre steg: 1) att bedöma vinjetterna, 2) att analysera vinjettbedömningarna 
statistiskt och, 3) att tolka och diskutera bedömningsprofilerna. Avsikten med den noggranna demonstrationen av verktygets/övningens konstruktion och genomförande är givetvis att i största möjliga mån möjliggöra för artikelns läsare att själva tillämpa och utveckla verktyget i sin egen framtida undervisning. Jag kommer genomgående att använda exempel från en övning som genomfördes våren 2012 på socionomutbildningen inom ramen för ett moment om professionella bedömningar om bruk/missbruk av alkohol och narkotika.

\section{ATT KONSTRUERA ETT VINJETTVERKTYG ENLIGT FAKTORIELLA SURVEYMETODENS PRINCIPER}

Detta avsnitt inleds med en introduktion till faktoriella surveymetoden och avhandlar sedan själva konstruktionen av FSM-verktyget, vilket sker i tre steg: 1) att bestämma vinjettdesignen, 2) att dra ett urval av vinjetter och 3) att färdigställa vinjetterna.

För ungefär 40 år sedan introducerade den amerikanske sociologen Peter Rossi faktoriella surveymetoden som ett strukturerat tillvägagångssätt för att studera sociala bedömningar (Rossi, 1979; Rossi \& Nock, 1982). Kategorin "sociala bedömningar" är mycket generell, och innefattar alla de bedömningar som i någon mån bestäms socialt, dvs. där det finns någon form av konsensus bland människor om vilka principer som är avgörande för bedömningen. Faktoriella surveymetoden lämpar sig särskilt väl för att undersöka just konsensus och variation i bedömningar, eller bedömningars sociala och individuella komponenter (Rossi \& Nock, 1982). Faktoriella surveymetoden beskrivs ofta som en hybrid, då den bygger på principer från både det faktoriella experimentet och den klassiska surveyundersökningen. ${ }^{2}$ Metoden har hittills framför allt tillämpats $i$ amerikansk forskning om föreställningar och attityder inom en rad sociologiskt relevanta områden, t.ex. i studier rörande universitetsstudenters och universitetsanställdas uppfattningar om sexuella trakasserier (Rossi \& Weber-Burdin, 1983), allmänhetens preferenser om medicinsk behandling för olika sjukdomar/tillstånd som kan leda till döden (Denk m.fl., 1997), samt politikers attityder gentemot migranter (Short \& Magaña, 2002; för en översikt, se Wallander, 2009). På senare år har den dock även börjat användas flitigt - och utvecklats metodologiskt - av en grupp forskare i Tyskland (t.ex. Sauer m.fl., 2011; Auspurg \& Hinz, 2015). Därtill har den under det senaste årtiondet särskilt uppmärksammats av forskare som studerar professionella bedömningar (Ludwick m.fl., 2004; Taylor, 2006; Wallander, 2008, 2012; Wallander \& Molander, 2014). De allra flesta existerande FSM-undersökningar brukar datamaterial bestående av respondenternas aggregerade bedömningar av ett flertal vinjetter (Wallander, 2009). Metoden kan dock även användas för att modellera bedömningar på 
individnivå (se t.ex. Jasso, 1988), och det är till följd av detta som den lämpar sig som pedagogiskt verktyg.

\section{Att konstruera FSM-verktyget - steg 1: Att bestämma vinjettdesignen}

Som nämnts ovan utgörs FSM-vinjetternas främsta särdrag av att de helt och hållet kan analyseras $i$ termer av sina dimensioner och dimensionsnivåer. En uppsättning av utvalda och i ord formulerade dimensioner och dimensionsnivåer kallas för en vinjettdesign. Figur 1 illustrerar två FSM-vinjetter från designen som utgör denna studies huvudexempel (se Figur 1; jfr Wallander \& Blomqvist, 2005).

\section{Figur 1. Två exempel på FSM-vinjetter}

Helene är en 38-årig kvinna som sporadiskt, dvs. ett par gånger i månaden, använder cannabis. Har bostad och arbetar som journalist. Lever tillsammans med sin partner, som också använder narkotika, med barn. Har ett mindre och något bräckligt socialt nätverk. Har en god fysisk hälsa men ger intryck av att vara något psykiskt instabil. Är själv något bekymrad över sitt bruk.

Är inte i behov av organiserad hjälp

Är i behov av organiserad hjälp

Peter är en 23-årig man som regelbundet, dvs. ett par gånger i veckan, dricker till berusning. Har bostad och studerar på lärarutbildning. Lever tillsammans med sin partner, som inte dricker, och har inga barn. Har ett mindre och något bräckligt socialt nätverk. Har en god fysisk och psykisk hälsa. Ser inte sitt bruk som något större problem.

Är inte i behov av organiserad hjälp

Är i behov av organiserad hjälp

Vid en första anblick går det att observera att dessa två vinjetter är mycket korta, men ändå innehåller en mängd information. Det går också att se att vinjetterna innehåller samma slags information. Konstruktionen av en vinjettdesign av det här slaget görs i fyra steg (jfr Wallander, 2008): Steg ett är att specificera den bedömning som skall göras, och att bestämma hur bedömningen i fråga skall mätas. I den aktuella övningen vill vi veta huruvida den beskrivna personen bedöms vara i behov av organiserad hjälp (för sitt bruk av alkohol eller narkotika) eller inte. ${ }^{3}$ Därefter väljer man ut ett antal dimensioner som antas kunna påverka bedömningen ifråga, och vars 
eventuella påverkan man vill undersöka. ${ }^{4}$ Som går att utläsa från vinjetterna ovan innehåller exempeldesignen både dimensioner som relaterar till själva bruket av alkohol eller narkotika, och dimensioner som beskriver personen $\mathrm{i}$ termer av kön, etnicitet, ålder och social klass. ${ }^{5}$ Steg tre är att bestämma hur dimensionerna skall varieras, dvs. hur många dimensionsnivåer de skall innehålla och hur dessa skall specificeras. I den utvalda vinjettdesignen innehåller exempelvis dimensionen "kön" två nivåer: man respektive kvinna, medan dimensionen "bruksmedel" består av fyra nivåer: alkohol, cannabis, kokain och amfetamin. ${ }^{6}$ Det fjärde och sista steget är att bestämma hur dessa nivåer skall operationaliseras, dvs. hur de skall formuleras $i$ ord. Vinjettdimensionen "bruksmönster" exempelvis har två nivåer, varav "sporadiskt" bruk operationaliseras som "ett par gånger i månaden" medan "regelbundet" bruk operationaliseras som "ett par gånger i veckan". 7 Tabell 1 ger en översikt av den aktuella vinjettdesignen.

\begin{tabular}{|c|c|c|}
\hline $\begin{array}{l}\text { Vinjettdimensioner } \\
\text { och nivåer }\end{array}$ & Vinjettformuleringar & $\%$ urval \\
\hline $\begin{array}{l}\text { Etnicitet } \\
\text { Svensk } \\
\text { Finsk } \\
\text { Mellanöstern } \\
\end{array}$ & $\begin{array}{l}\text { Fyra namn för respektive kön } \\
\text { Fyra namn för respektive kön } \\
\text { Fyra namn för respektive kön }\end{array}$ & $\begin{array}{l}33,3 \\
33,3 \\
33,3\end{array}$ \\
\hline $\begin{array}{l}\text { Ålder } \\
\text { Yngre } \\
\text { Medelålders } \\
\text { Äldre }\end{array}$ & $\begin{array}{l}\text { är en 23-årig } \\
\text { är en 38-årig } \\
\text { är en 58-årig }\end{array}$ & $\begin{array}{l}33,3 \\
33,3 \\
33,3\end{array}$ \\
\hline $\begin{array}{l}\text { Kön } \\
\text { Man } \\
\text { Kvinna }\end{array}$ & $\begin{array}{l}\text { man } \\
\text { kvinna }\end{array}$ & $\begin{array}{l}50,0 \\
50,0\end{array}$ \\
\hline $\begin{array}{l}\text { Bruksmönster } \\
\text { Sporadiskt } \\
\text { Regelbundet }\end{array}$ & $\begin{array}{l}\text { som sporadiskt, dvs. ett par gånger i månaden, } \\
\text { som regelbundet, dvs. ett par gånger i veckan, }\end{array}$ & $\begin{array}{l}50,0 \\
50,0\end{array}$ \\
\hline $\begin{array}{l}\text { Bruksmedel } \\
\text { Alkohol } \\
\text { Cannabis } \\
\text { Kokain } \\
\text { Amfetamin }\end{array}$ & $\begin{array}{l}\text { dricker till berusning. } \\
\text { använder cannabis. } \\
\text { använder kokain. } \\
\text { använder amfetamin. }\end{array}$ & $\begin{array}{l}25,0 \\
25,0 \\
25,0 \\
25,0\end{array}$ \\
\hline $\begin{array}{l}\text { Bostad } \\
\text { Har bostad }\end{array}$ & Har bostad & 100,0 \\
\hline $\begin{array}{l}\text { Social klass } \\
\text { Marginaliserad } \\
\text { Arbetarklass } \\
\text { Medelklass } \\
\text { Väletablerad }\end{array}$ & $\begin{array}{l}\text { men är arbetslös. } \\
\text { och arbetar som städare/mentalskötare. } \\
\text { och arbetar som lärare/journalist.* } \\
\text { och arbetar som advokat/civilingenjör.* }\end{array}$ & $\begin{array}{l}25,0 \\
25,0 \\
25,0 \\
25,0\end{array}$ \\
\hline $\begin{array}{l}\text { Partner } \\
\text { Ensamstående } \\
\text { Partner som inte } \\
\text { brukar }\end{array}$ & $\begin{array}{l}\text { Är ensamstående, } \\
\text { Lever tillsammans med sin partner, som inte } \\
\text { dricker/använder narkotika, }\end{array}$ & $\begin{array}{l}33,3 \\
33,3\end{array}$ \\
\hline
\end{tabular}




\begin{tabular}{|l|l|l|}
\hline Partner som brukar & $\begin{array}{l}\text { Lever tillsammans med sin partner, som också } \\
\text { dricker/använder narkotika }\end{array}$ & 33,3 \\
\hline $\begin{array}{l}\text { Barn } \\
\text { Barna barn }\end{array}$ & $\begin{array}{l}\text { och har inga barn. } \\
\text { med barn. }\end{array}$ & 50,0 \\
\hline $\begin{array}{l}\text { Socialt nätverk } \\
\text { Svagt } \\
\text { Starkt }\end{array}$ & $\begin{array}{l}\text { Har ett mindre och ganska bräckligt socialt nätverk. } \\
\text { Fysisk hälsa }\end{array}$ & 50,0 \\
God fysisk hälsa & Har ett stort och stabilt socialt nätverk. & 50,0 \\
\hline $\begin{array}{l}\text { Psykisk hälsa } \\
\text { God psykisk hälsa } \\
\text { Psykiskt instabil }\end{array}$ & $\begin{array}{l}\text { och psykisk hälsa.** } \\
\text { men ger intryck av att vara något psykiskt instabil. }\end{array}$ & 100,0 \\
\hline $\begin{array}{l}\text { Problemuppfälsa } \\
\text { Bruk inget problem } \\
\text { Bekymrad över bruk }\end{array}$ & $\begin{array}{l}\text { Ser inte sitt bruk som något större problem. } \\
\text { Är själv något bekymrad över sitt bruk. }\end{array}$ & 50,0 \\
\hline
\end{tabular}

* När personen var ung beskrevs han/hon som student på den aktuella utbildningen.

** Vid "god psykisk hälsa" slogs formuleringen av fysisk och psykisk hälsa ihop.

Tabell 1. Vinjettdesign och vinjetturvalets sammansättning

\section{Att konstruera FSM-verktyget - steg 2: Att dra ett urval av vinjetter}

Tabell 1 ovan upplyser om att vinjettdesignen innehåller 13 dimensioner med mellan en och fyra nivåer. ${ }^{8}$ Genom att multiplicera antalet nivåer för samtliga dimensioner, dvs. $3 * 3 * 2 * 2 * 4 * 1 * 4 * 3 * 2 * 2 * 1 * 2 * 2$, får vi fram antalet unika vinjetter, i det här fallet 27,648 stycken. Denna vinjettpopulation brukar benämnas vinjettuniversum (Rossi \& Nock, 1982). Det säger sig självt att endast en bråkdel av dessa vinjetter kan bedömas inom ramen för en övning med studenter. En finess med faktoriella surveymetoden (om den jämförs med det traditionella faktoriella experimentet) är just att antalet vinjetter som faktiskt bedöms kan vara betydligt färre än de som ingår i universumet, utan att man därmed förlorar möjligheten att generalisera resultatet (ibid.).

Reduktionen av vinjetter görs genom att man - enligt principer från den klassiska surveyundersökningen - drar ett urval av vinjetter från universumet. ${ }^{9}$ Detta urval kan dras antingen slumpmässigt, vilket är det vanligaste (Wallander, 2009), eller systematiskt. ${ }^{10}$ I det aktuella exemplet används ett så kallat "D-efficiency-" urval, vilket är ett slags systematiskt urval som blivit allt vanligare på senare år (Dülmer, 2007, 2016; Auspurg \& Hinz, 2015). ${ }^{11}$ Till skillnad från det slumpmässiga urvalet, där slumpen bestämmer vilka vinjetter som skall ingå i urvalet, innebär D-efficiency-urvalet att man med ett dataprograms hjälp (i det här fallet Statistical Analysis Software [SAS], se exempelvis Cody, 2015), drar det "bästa möjliga urvalet" från vinjettuniversumet, dvs. det urval som bäst speglar vinjettuniversumets två egenskaper. Den första egenskapen utgörs av balansen mellan nivåerna inom varje dimension. Med andra ord skall vinjetturvalet idealiskt sett innehålla lika många kvinnor som män, lika många som använder alkohol, cannabis, kokain 
och amfetamin, osv. Den andra egenskapen brukar benämnas som ortogonalitet, med vilket här avses att vinjettdimensionerna inte korrelerar med varandra (korrelationerna $=0$ ). I ett exemplariskt vinjetturval skall korrelationerna mellan dimensionerna vara så små som möjligt. Ett vinjetturval med god balans och approximativ ortogonalitet ger hög statistisk power, dvs. goda möjligheter att få fram så exakta estimat som möjligt av sambanden mellan vinjettdimensionerna och bedömningarna (Dülmer, 2007, 2016). ${ }^{12}$ Det urval som användes $i$ den aktuella övningen innehåller 96 vinjetter; bland dessa är nivåbalansen perfekt (se kolumnen \% urval i Tabell 1) och den högsta korrelationen mellan två dimensioner är 0,042 .

\section{Att konstruera FSM-verktyget - steg 3: Att färdigställa vinjetterna}

Oberoende av vilket urvalsförfarande man väljer (slumpmässigt eller systematiskt) resulterar det alltid i en datamatris (förslagsvis i Excel), med en rad för varje vinjett $i$ urvalet och en kolumn för varje vinjettdimension, och med siffror som representerar dimensionernas olika nivåer för var och en av samtliga utvalda vinjetter. I det aktuella fallet bestod datamatrisen således av 96 rader och 13 kolumner, och med siffror mellan 1 och 4 (beroende på antalet dimensionsnivåer). Vinjetterna färdigställdes sedan (siffrorna omvandlades till text, se exemplen i Figur 1) i ett specialgjort mjukvaruprogram, vilket genererade ett Word-dokument innehållandes 96 vinjetter med medföljande fråga och svarsalternativ. ${ }^{13}$ Observera att denna transformering även kan göras genom att kombinera Excel och brevfunktionen i Word (Tornberg \& Wallander, 2018).14

\section{ATT ANVÄNDA FSM-VINJETTER SOM PEDAGOGISKT VERKTYG}

Som nämndes ovan är det aktuella pedagogiska verktyget flexibelt $\mathrm{i}$ den meningen att det kan användas i olika varianter, allt efter undervisningens syfte. I den här artikeln presenteras enbart själva kärnan i övningen, dvs. hur man gör för att få fram en så kallad bedömningsprofil (en sammanställning av varje students bedömningar och bedömningsgrunder) och hur man tolkar profilen och drar slutsatser grundade i dess innehåll. Kärnövningen utgörs av tre steg: 1) Först bedömer studenterna individuellt vinjetterna. 2) Sedan gör studenterna (eller läraren) statistiska analyser av bedömningarna och sammanställer dessa i individuella profiler. 3) Slutligen tolkar och diskuterar studenterna och läraren profilerna, i små grupper och/eller i storgrupp.

\section{Att använda FSM-verktyget - steg 1: Att bedöma vinjetterna}

När vinjetterna är färdigkonstruerade i den meningen att de består av ett visst antal (här 96) korta fiktiva fall, är de klara att användas som pedagogiskt verktyg. Tidsåtgången för det här delmomentet brukar variera mellan 40 och 
90 minuter. Vilka instruktioner som ges till studenterna är olika beroende på syftet med övningen, men det är angeläget att alltid poängtera att det inte finns några riktiga eller felaktiga svar/bedömningar, att studenterna skall välja det svarsalternativ som de själva tycker är mest adekvat, att de får försöka bortse från det faktum att vinjetterna ser väldigt lika ut (alla vinjetter är ju i regel unika) och läsa varje fall för sig, samt att det är viktigt att finna en balans när det gäller hur mycket tid som läggs på varje vinjett. $\AA$ ena sidan är vinjetterna många, vilket $\mathrm{i}$ sig gör att tiden per vinjett måste ransoneras. $\AA$ andra sidan brukar övningen inte ta så lång tid som man initialt uppskattar, vilket innebär att det är fullt möjligt att faktiskt slappna av och ta sig tid att tänka.

Precis som i alla typer av undersökningar där man är ute efter att mäta någonting, är den aktuella övningens validitet avhängig av att deltagarna har en gemensam förståelse av frågan (och svarsalternativen) som de har att ta ställning till i anslutning till vinjetterna (jfr begreppsvaliditet). Därför är det av vikt att man som lärare tar tillfället $i$ akt att - vid introduktionen av övningen, och tillsammans med studenterna - bringa klarhet i den definitionsmässiga avgränsningen av den bedömning som står i fokus. I den aktuella exempeldesignen fick studenterna följande instruktioner till uppgiften: ${ }^{15}$

\footnotetext{
"Uppgiften består av att bedöma huruvida den person som beskrivs $\mathrm{i}$ vinjetten är $i$ behov av organiserad hjälp eller inte.

- Om du bedömer att personen inte är i behov av organiserad bjälp kan det vara av två skäl: (1) du bedömer att personen inte har något problem; (2) du bedömer att personen har problem, men att han/hon kan lösa detta utan organiserad hjälp;

- Om du bedömer att personen är $i$ behov av organiserad bjälp kan man tänka sig att han/hon tillhör målgruppen för någon av följande organisationer: socialtjänstens missbruksvård, landstingets beroendevård, en frivillig organisation."
}

\section{Att använda FSM-verktyget - steg 2: Att analysera vinjettbedömningarna statistiskt}

Övningens numeriska datamaterial utgörs av informationen i vinjetterna (varje vinjettdimension utgör en variabel) och av studenternas bedömningar av vinjetterna (bedömningarna utgör också en variabel). Datamaterialet sammanställs genom att man importerar den ursprungliga vinjettdesignen från Excel (se ovan) till ett specifikt statistikprogram (i detta fall Statistical Package for the Social Sciences [SPSS]; Pallant, 2016), och sedan matar in vinjettbedömningarna i en separat kolumn/variabel. De statistiska analyserna görs på individnivå, och därför finns det i teorin lika många datamaterial som det finns studenter i gruppen. Som nämndes ovan kan de statistiska analyserna 
göras antingen av läraren eller av studenterna själva, inom ramen för en lärarledd datalaboration.

Vilka statistiska analyser som görs är avhängigt av hur vinjetturvalet ser ut, i termer av hur höga korrelationerna mellan dimensionerna är, och av hur man har valt att mäta studenternas bedömningar. Eftersom korrelationerna mellan vinjettdimensionerna $i$ vårt exempelurval är mycket låga räcker det med bivariat statistik för att analysera sambanden mellan vinjettdimensionerna och bedömningarna. Om korrelationerna hade varit högre (vilket alltid är fallet i små slumpmässiga urval) krävs multivariat analys för att separera effekterna av vinjettdimensionerna på bedömningarna (se exempelvis Wallander \& Laanemets, 2017). ${ }^{16}$ Eftersom bedömningarna i den aktuella övningen mäts med dikotoma svarsalternativ utgörs den univariata analysen av relativa frekvenser (\%) av bedömningsvariabeln och den bivariata analysen av korstabeller (där varje vinjettdimension korsas med bedömningsvariabeln) med tillhörande korrelationskoefficient (Cramérs' V). ${ }^{17}$ Om bedömningsmomentet hade inkluderat en kontinuerlig svarsskala hade vi istället fått ta fram ett medelvärde för bedömningsvariabeln (univariat analys), och sedan fått testa skillnaderna mellan bedömningarnas medelvärden för samtliga nivåer inom varje dimension, $\mathrm{i}$ form av $\mathrm{t}$-test och variansanalys (bivariat analys). Effektmåttet Eta2 (som kan räknas ut manuellt utifrån resultaten av t-test och variansanalyser; Pallant, 2016) hade kunnat användas som motsvarighet till Cramér's V.

Resultaten av analyserna sammanställs sedan i individuella bedömningsprofiler, varav ett exempel återfinns i Tabell 2.

\begin{tabular}{|l|c|c|c|c|}
\hline $\begin{array}{l}\text { Vinjettdimensioner } \\
\text { och nivåer }\end{array}$ & Cr.V & Rang & $\begin{array}{c}\text { Inte i behov av } \\
\text { organiserad hjälp } \\
\text { (\%) }\end{array}$ & $\begin{array}{c}\text { I behov av } \\
\text { organiserad } \\
\text { hjälp (\%) }\end{array}$ \\
\hline Totalt & & & 47,8 & 52,2 \\
\hline Etnicitet & 0,040 & 9 & 48,4 & 51,6 \\
Svensk & & & 50,0 & 50,0 \\
Finsk & & & 45,2 & 54,8 \\
Mellanöstern & 0,107 & 7 & 46,7 & 53,3 \\
\hline Alder & & & 41,9 & 58,1 \\
Yngre & & & 54,8 & 45,2 \\
Medelålders & & & 47,7 & 52,3 \\
Äldre & 0,002 & 10 & 47,9 & 52,1 \\
\hline Kön & & & 56,5 & 43,5 \\
Man & & 6 & 39,1 & 60,9 \\
Kvinna & 0,174 & & & \\
\hline Bruksmönster & & & & \\
Sporadiskt & & & \\
Regelbundet & 0,366 & 3 & & \\
\hline Bruksmedel & &
\end{tabular}




\begin{tabular}{|l|c|c|c|c|}
\hline Alkohol & & & 71,4 & 28,6 \\
Cannabis & & & 60,9 & 39,1 \\
Kokain & & & 25,0 & 75,0 \\
Amfetamin & & & 37,5 & 62,5 \\
\hline Social klass & 0,219 & 5 & 31,8 & 68,2 \\
Marginaliserad & & & 45,8 & 54,2 \\
Arbetarklass & & & 50,0 & 50,0 \\
Medelklass & & & 62,5 & 37,5 \\
Väletablerad & 0,293 & 4 & & 53,3 \\
\hline Partner & & & 65,6 & 34,4 \\
Ensamstånde & & & 30,0 & 70,0 \\
Partner som inte brukar & & & 68,8 & 31,2 \\
Partner som brukar & 0,438 & 2 & 25,0 & 75,0 \\
\hline Barn & & & 45,7 & 54,3 \\
Inga barn & & & 50,0 & 50,0 \\
Barn & 0,044 & 8 & & \\
\hline Socialt nätverk & & & 47,9 & 52,1 \\
Svagt & & & & 52,3 \\
Starkt & 0,002 & 10 & & 28,7 \\
\hline Psykisk hälsa & & & \\
God psykisk hälsa & & & & \\
Psykiskt instabil & & & & \\
\hline Problemuppfattning & 0,456 & 1 & & \\
Bruk inget problem & & & & \\
Bekymrad över bruk & & & & \\
\hline
\end{tabular}

Tabell 2. Ett exempel på en bedömningsprofil

\section{Att använda FSM-verktyget - steg 3: Att tolka och diskutera bedömningsprofilerna}

Den seminariediskussion som följer - i smågrupper och/eller i storgrupp utgår från resultaten i bedömningsprofilerna, vilka åskådliggör studenternas individuella bedömningar och bedömningsgrunder i den aktuella situationen, i det här fallet behovet av organiserad hjälp för alkohol- eller narkotikabruk. Med profilen som grund får studenterna möjlighet att reflektera kring, ifrågasätta, diskutera och argumentera för sina resultat.

Diskussionen struktureras företrädesvis enligt de tre slags resultat som finns i bedömningsprofilen. Det första resultatet - tillämpat på den aktuella vinjettdesignen - ger en indikation om studentens allmänna benägenhet att göra bedömningen att någon är i behov av organiserad hjälp. Exempelprofilen i Tabell 2 visar att studenten ifråga har bedömt att 52,2 procent av vinjettpersonerna har behov av organiserad hjälp och att 47,8 procent inte har behov av sådan hjälp. Helt isolerade ger dessa siffror inte speciellt mycket information. De får ett helt annat värde då de jämförs med övriga kurskamraters siffror. Som exempel kan nämnas att en annan student i samma grupp bedömde att 88,5 procent av vinjetterna hade behov av organiserad hjälp medan en tredje bedömde att endast 36,5 procent av samma uppsättning 
med fiktiva personer hade ett sådant hjälpbehov. Tillämpningen av verktyget har visat att det brukar finnas relativt stor variation i studenternas bedömningar, och detta är ju naturligtvis en god förutsättning för en levande diskussion.

Den andra typen av resultat handlar om bur stor inverkan de respektive vinjettdimensionerna har på studentens bedömningar om behovet av organiserad hjälp. Kolumnen märkt Cramér's V presenterar en korrelationskoefficient per vinjettdimension. Dessa koefficienter kan gå mellan 0 (inget samband) och 1 (perfekt samband), och ju högre värde, desto större vikt lade studenten vid dimensionen ifråga när hon bedömde vinjetterna. Koefficienternas värden används för att rangordna vinjettdimensionerna efter deras respektive betydelse (se kolumnen märkt Rang). Bedömningsprofilen i exemplet ovan visar att "problemuppfattning" spelade störst roll för den aktuella studentens bedömningar, följt av "barn" och "bruksmedel". Korrelationen/Sambandet ${ }^{18}$ mellan problemuppfattning och bedömningarna om organiserad hjälp har ett värde på 0,456 , medan de minst betydelsefulla dimensionerna, "kön" och "psykisk hälsa" uppvisar värden nära noll $(0,002) \cdot{ }^{19}$ Även när det gäller rangordningen mellan dimensionerna brukar det finnas variation i studentgruppen. Nämnas kan exempelvis att flera studenter i den aktuella gruppen lade störst vikt vid personens "bruksmönster" - en dimension som inte fanns med bland ovanstående students tre högst rangordnade dimensioner.

Den tredje och sista typen av resultat visar bur vinjettdimensionerna paverkar studentens bedömningar om organiserad hjälp. Med andra ord kan man se hur stor andel bland vinjettpersoner med olika egenskaper som bedömts vara $\mathrm{i}$ behov respektive inte $\mathrm{i}$ behov av organiserad hjälp. För att ta dimensionen "bruksmedel" i profilen ovan som exempel, gjorde studenten oftare bedömningen att det fanns ett behov av organiserad hjälp när vinjettpersonen använde kokain (75\%) än när (i princip) samma person använde alkohol $(28,6)$, cannabis $(39,1)$ eller amfetamin $(62,5)$. För att ge en bild av variationen $\mathrm{i}$ studentgruppen kan nämnas att det bland övriga studenter i den aktuella gruppen fanns profiler där samtliga användare av kokain och amfetamin bedömts vara $i$ behov av hjälp, eller där cannabisanvändare bedömts ha ett mindre hjälpbehov än alkoholbrukare.

Som antytts ovan kan dessa resultat stötas och blötas på olika vis. Detta kommer att beröras i den avslutande diskussionen nedan.

\section{AVSLUTANDE DISKUSSION}

Syftet med artikeln var att introducera och demonstrera ett tidigare oprövat sätt att använda FSM-vinjetter som pedagogiskt verktyg i högre utbildning. I avsnittet nedan relateras FSM-verktyget inledningsvis till den mer traditionella 
casemetodiken. Därefter följer en längre diskussion om vilka typer av bedömningar som kan analyseras med hjälp av FSM-verktyget, vilka olika lärandemoment som är (eller potentiellt kan vara) inbakade i övningen, samt om verktygets praktiska användning. Avslutningsvis kommenteras FSMverktygets plats inom ramen för den mer generella kvalitetsutvecklingen av högre utbildning.

Som nämndes inledningsvis åtnjuter FSM-verktyget ett flertal av den traditionella casemetodikens fördelar, som exempelvis att studenterna får möjlighet att identifiera och tillämpa relevant kunskap på praktiska problem, samtidigt som de tränar sitt kritiska tänkande, sin skicklighet att argumentera för sin ståndpunkt och sin förmåga att hantera och respektera avvikande åsikter (jfr inledningen). Den främsta exklusiva fördelen med FSM-vinjetter är att de möjliggör identifikationen av bedömningsgrunder som den enskilde studenten inte tidigare har varit medveten om (t.ex. Wallander, 2012). Dessa omedvetna grunder innefattar både omedvetet existerande samband (att en vinjettdimension har en icke-förväntad effekt på bedömningarna) och omedvetet icke-existerande samband (att en vinjettdimension inte har den förväntade effekten på bedömningarna). Detta skapar ett unikt tillfälle för reflektion över eventuella fördomar baserade på stereotyper kopplade till exempelvis klass, kön och etnicitet, och för en diskussion om användningen av så kallad "tyst kunskap" i bedömningar (jfr Polanyi, 1966). I övrigt finns avsevärda skillnader mellan den mer traditionella casemetodiken och FSMverktyget. Medan de traditionella vinjetterna vanligen är långa och komplexa och själva står i fokus för diskussionen, är FSM-vinjetter korta och grova och utgör egentligen bara en del av underlaget för de statistiska analyserna, vars resultat sedan används som diskussionsmaterial. Och medan traditionella vinjetter anses vara av god kvalitet om de berättar en bra historia, är autentiska, har direkt relevans för läsaren och uppmuntrar (eller rentutav provocerar fram) bedömningar (jfr Herreid, 1997), grundas värderingen av FSM-vinjetters kvalitet på forskarens kriterier för val av dimensioner och nivåer, operationaliseringen av dimensionsnivåerna, osv. (se ovan). Sannolikt skulle det vara fruktbart att kombinera användningen av traditionella case och FSM-vinjetter inom ramen för ett och samma undervisningsmoment, eftersom man då skulle kunna dra fördel både av casets höga grad av autenticitet, vilket innebär att diskussionsmaterialet ifråga har en hög extern validitet, och av FSM-vinjetternas experimentella kontroll, vilket istället ger ett empiriskt diskussionsunderlag med hög intern validitet.

Som nämnts ett flertal gånger ovan är FSM-verktyget mycket flexibelt, både vad gäller upplägg och användning. I stort sett vilken bedömning som helst kan undersökas och analyseras inom ramen för övningen. För att ge några uppslag kan nämnas att Guillermina Jasso (2006) har föreslagit att faktoriella surveymetoden kan användas för att studera så kallade "positive beliefs" och "normative judgements". Med "positive belief" menas en 
uppfattning/föreställning om hur/vad någonting är, medan "normative judgement" åsyftar en bedömning om hur/vad någonting borde vara. Den första av dessa två typer av bedömningar involverar bland annat begreppsdefinitioner, och kan med fördel appliceras i undervisning om sociala problem och deras konstruktion. I skrivande stund genomför undertecknad, tillsammans med Jan Blomqvist (Blomqvist \& Wallander, 2017), en faktoriell surveystudie om olika gruppers uppfattningar om innebörden av begreppen "alkoholism", "alkoholberoende", "alkoholmissbruk", och "riskdrickande". En FSM-övning baserad på en sådan vinjettdesign skulle ge studenter möjlighet att, med utgångspunkt i en empiriskt grundad reflektion över sina egna begreppsdefinitioner, ta sig an mer allmänna spörsmål kring hur problematisk eller avvikande alkoholkonsumtion uppfattas och hanteras idag (och har uppfattats/hanterats genom tiderna). Den andra typen av bedömning - en bedömning om hur/vad någonting borde vara - kan lämpligen användas inom ramen för undervisning om normer och värderingar. Exempel på normativa bedömningar för vilka det redan finns konstruerade FSM-designer är bedömningar om "huruvida ett visst straff för ett visst brott är för hårt eller för lindrigt” (Miller m.fl., 1991) och bedömningar om "vilka skyldigheter vuxna barn har gentemot frånskilda föräldrar och styvföräldrar" (Coleman m.fl., 2005). När det gäller typiska professionella bedömningar skulle man kunna beskriva "diagnosen" som en uppfattning om vilket problem man har att göra med $\mathrm{i}$ en viss situation (positive belief), medan "(be-)handlingsrekommendationen" utgör en uppfattning om vad man bör göra för att lösa ett visst problem (normative judgement; jfr Wallander, 2012; Wallander \& Molander, 2014). Det är fullt görligt att skapa en FSM-design med vilken man kan analysera båda dessa typer av bedömningar, var för sig och i relation till varandra. En sådan design skulle exempelvis kunna rikta sig till lärarstudenter, och behandla deras uppfattningar om "allvarlighet" i olika situationer där barn riskerar att fara illa, samt den uppskattade sannolikheten att de, i var och en av de situationer som beskrivs i vinjetterna, skulle "göra en orosanmälan" till socialtjänsten (jfr Webster m.fl., 2005). För en detaljerad kategorisering av de bedömningar som har studerats med hjälp av faktoriella surveymetoden mellan 1982 och 2006, se Wallanders (2009) litteraturöversikt.

FSM-verktygets kärnövning har tre beståndsdelar, vilka var för sig involverar olika lärandemoment. Inom ramen för professionsutbildningar skulle exempelvis det inledande bedömningsmomentet, där var och en av de deltagande studenterna individuellt får bedöma ett stort antal korta vinjetter, kunna betraktas som en övning i att gång efter gång behöva ta ställning i en och samma praktikrelevanta bedömningssituation - någonting som i sig brukar beskrivas som ett led i utvecklandet av expertis inom en specifik domän (jfr Ericsson, 2006). Om man sedan låter studenterna själva göra de statistiska analyser vars resultat tecknas ned i bedömningsprofilerna, ges 
möjlighet till träning $\mathrm{i}$ genomförande av grundläggande statistisk analys, något som är särskilt efterfrågat inom ämnen där det är vanligt med så kallad "statistikängslan" bland studenterna (Onwuegbuzie \& Wilson, 2003), och där man önskar att studenterna under utbildningens gång skall tillägna sig färdigheter i att resonera med hjälp av statistik ("statistical literacy", jfr Nikiforidou, m.fl., 2010). Tilläggas bör att den aktuella övningens datalaboration som regel frambringar en hög grad av motivation hos de studenter som deltar - de vill ju givetvis kunna få fram och tolka (rätt!) sina egna bedömningsgrunder. För att genomföra den grundläggande statistiska analys som presenterats ovan behövs inga förkunskaper i statistisk analys eller SPSS (givet att datalaborationen är lärarledd). Om man så önskar kan man naturligtvis använda FSM-verktyget med det primära syftet att ge övning i statistisk analys, och då inte bara univariat och bivariat analys, utan också multivariat analys. Kärnövningens tredje och sista moment - vilket egentligen utgör övningens mest centrala beståndsdel - består i tolkningen, jämförelsen och diskussionen av de resultat som presenteras i bedömningsprofilerna. För att dessa diskussioner skall bli fruktbara krävs naturligtvis att läraren skapar ett sammanhang, där studenternas intresse väcks och där deras aktiva engagemang stimuleras (Lynn, 1999). Av särskild vikt är att diskussionsklimatet främjar framförandet av diametralt olika uppfattningar, och att studenterna känner sig manade att stå upp för och rättfärdiga sina bedömningsgrunder, samtidigt som det naturligtvis också måste finnas utrymme för dem att ifrågasätta, och kanske rentav revidera (med hänsyn taget till det som kommer fram i diskussionen) sina tidigare uppfattningar om vem som är i behov av organiserad hjülp. För läraren handlar det om en balansgång mellan att visa acceptans för många olika uppfattningar och att stundtals inta rollen som djävulens advokat (jfr ibid.). Även om tolkningen av själva resultaten i bedömningsprofilerna strikt följer statistikens regler, är diskussionens form och struktureringen av dess innehåll i princip lika anpassbar som när man använder traditionell casemetodik, vilket $i$ det här fallet också innebär att man kan få övning i flera av de färdigheter som brukar förknippas med casemetodik (se inledningen). Sammantaget kan kärnövningen - med dess tre moment - utan problem genomföras under loppet av en dag. Naturligtvis är det möjligt att utvidga övningen med fler moment, exempelvis genom att använda bedömningsprofilerna som underlag för en mer formaliserad argumentationsanalysövning (ett exempel på en sådan övning ges i Wallander och Molander (2016), där bedömningsprofilen kopplas till Stephen Toulmins modell av argumentet (1958/2003)). Eftersom kärnövningen tar mycket lite tid i anspråk kan den i praktiken beredas utrymme i de allra flesta kurser, vilket innebär att FSM-verktyget tillhör de pedagogiska verktyg som kan nyttjas inom ramen för en integrerad (jfr "embedded") approach för att öva generiska färdigheter (jfr Drummond, m.fl., 1998). 
Precis som med alla vetenskapliga metoder och pedagogiska verktyg är det möjligt att problematisera och diskutera olika aspekter av FSM-verktyget. Något som de allra flesta som hör talas om övningen för första gången reagerar över är antalet vinjetter som bedöms - är det möjligt (eller realistiskt) att bedöma 96 vinjetter? Risken med ett stort antal vinjetter är att studenterna efter ett tag kan bli trötta och ofokuserade, och att det påverkar stringensen $i$ deras bedömningar, och sedermera även resultatens reliabilitet (jfr effekter av fatigue, Sauer m.fl., 2011). I praktiken skulle sådana negativa effekter kunna spåras, genom att man jämför bedömningarna av de första 46 vinjetterna med bedömningarna av de sista 46 vinjetterna. Vid en översiktlig jämförelse av det slaget på samtliga bedömningsprofiler från den aktuella studentgruppen gick det att se att vissa studenter ändrade bedömningsprinciper (jfr bedömningsgrunder) efter ett tag, medan andra studenter använde samma principer genom hela övningen. Problemet med den här typen av jämförelse är emellertid att man inte utan vidare kan dra slutsatsen att förändrade principer utgör konsekvensen av trötthetseffekter. Det skulle lika gärna kunna vara så att övningen i sig utgör en läroprocess, och att studenterna fullt medvetet ändrar bedömningsprinciper under övningens gång. Eventuellt skulle en statistisk jämförelse mellan tidigt respektive sent kommande vinjetter kunna ingå i övningsuppgiften, kombinerat med en studentdiskussion om vad eventuella förändringar kan ha sin grund i (jfr Wallander \& Molander, 2016). Ett alternativt tillvägagångssätt för att hantera risken för fatigue-effekter är naturligtvis att minska antalet vinjetter. Det ursprungliga motivet till att välja så pass många vinjetter för övningen baserades på en försiktighetsåtgärd (att ett högre antal observationer generellt ger större möjligheter att identifiera eventuella samband mellan vinjettdimensionerna och bedömningarna), samtidigt som det brukar anses lämpligt att tolkningar $i$ termer av procentsatser görs på ett antal som inte är alltför mycket lägre än 100. Om man vid konstruktionen av vinjettdesignen tar hänsyn till olika principer om antalet dimensionsnivåer, m.m. (se Auspurg \& Hinz, 2015), är det dock möjligt att dra betydligt mindre D-efficiency-urval, som trots sin ringa storlek har de egenskaper (god nivåbalans och approximativ ortogonalitet, jfr ovan) som maximerar möjligheterna att identifiera eventuella samband. Vid den framtida utvecklingen av verktyget kommer jag att dra nytta av detta.

Som redogjorts för ovan skapas en faktoriell vinjettdesign i flera steg, vilka alla rymmer olika substantiella och metodmässiga överväganden. Om man av dessa skäl tvekar att använda verktyget $i$ sin undervisning kan det vara bra att veta att det redan finns en mängd färdiga vinjettdesigner (se ovan och Wallander, 2009). Dessa kan enkelt revideras och anpassas till den aktuella kontexten. Eller varför inte dela in studenterna i två grupper, och låta dem konstruera varsin vinjettdesign, som sedan används i den andra gruppen (jfr Jones \& Russell, 2008)? Här bör dock noteras att full kännedom om hur metoden fungerar - dvs. dess experimentella egenskaper - skulle kunna föra 
med sig en ökad risk för socialt önskvärda resultat (kunskap om metoden ger nämligen ökade möjligheter att "manipulera" resultaten). Denna nackdel skulle kunna vara extra kännbar i övningar där man är speciellt intresserad av att identifiera eventuella effekter av exempelvis klass, kön och etnicitet på bedömningarna (jfr Wallander, 2012).

Sist men inte minst vill jag säga något kort om FSM-verktygets roll inom ramen för en mer generell kvalitetsutveckling av högre utbildning. Faktoriella surveymetoden är ursprungligen en forskningsmetod - en mycket systematisk och komplex metod för att studera bedömningar. Att göra om en forskningsmetod till ett pedagogiskt verktyg är ingen dum idé, särskilt med tanke på att de olika vetenskapliga principer som finns för att producera reliabel och valid kunskap har sina synligaste uttryck i de metoder vi forskare använder, och eftersom dessa principer också utgör kärnan i den kunskap vi önskar att våra studenter inhämtar inom ramen för sina högre studier. FSMverktyget är med största sannolikhet inte det första exemplet på en sådan "applikation", och förhoppningsvis inte heller det sista. I skrivande stund har det ovan introducerade verktyget inte ännu blivit formellt validerat, i den meningen att dess förmodade positiva effekter på studenternas lärande har blivit utvärderade (enligt gängse metoder med för- och eftermätning, samt kontrollgrupp). Nämnas bör dock att övningen alltid har åtföljts av mer informella studentvärderingar, vilka varit genomgående positiva (se Wallander \& Molander, 2016). En formell validering av FSM-verktyget är således en uppgift för framtida forskning.

\section{TACK}

Ett varmt tack riktas till PD Dr. Hermann Dülmer, Universität zu Köln, som drog studiens vinjetturval (D-efficiencyurvalet).

\section{NOTER}

1 "Case-method teaching" kan innefatta fall som är helt och hållet fiktiva eller verkliga, eller fall som har viss verklighetsanknytning, men som har vidareutvecklats $i$ pedagogiskt syfte (Lynn, 1999).

2 Metoden har stora likheter med så kallade discrete choice-experiment (används bland annat inom hälsoekonomi; jfr Clark m.fl., 2014) och med conjoint analysis (används bland annat inom forskning om marknadsföring; jfr Green m.fl., 2001).

3 Den aktuella bedömningsuppgiften inkluderar dikotoma svarsalternativ. Bedömningen kan naturligtvis också göras på en kontinuerlig skala. I en studie om bedömningar av våld i nära relationer bad vi deltagarna bedöma allvarlighetsgraden $\mathrm{i}$ 
beskrivningar av våldssituationer på en skala mellan 0 (inte alls allvarligt) och 10 (mycket allvarligt; Wallander \& Laanemets, 2017).

4 Enligt Guillermina Jasso (2006), en av de forskare som framgångsrikt använt faktoriella surveymetoden sedan 1970-talet, bör valet av vinjettdimensioner guidas av "tidigare teori och forskning, utomteoretiska resonemang och vedertagen visdom" (s. 342 ).

5 Antalet vinjettdimensioner kan variera, men allmänt rekommenderas idag att man håller sig till nio eller färre dimensioner (Auspurg \& Hinz, 2015). Denna rekommendation har sitt ursprung $\mathrm{i}$ en klassisk text (Miller, 1956), vars främsta budskap är att människans hjärna endast kan processa mellan fem och nio (sju plus minus två) olika delar av information samtidigt.

${ }^{6}$ En allmän regel vid valet av dimensionsnivåer är att de skall variera så pass mycket att man fångar den samvariation som kan tänkas finnas mellan dimensionen ifråga och bedömningarna. En dimensionsnivå bör dock inte ha ett så "extremt" värde att den totalt predicerar en viss bedömning. Om vi exempelvis hade valt att ha med heroin bland våra bruksmedel (heroin brukar skattas som den mest beroendeframkallande och farliga drogen, t.ex. Samuelsson m.fl., 2013) kan man tänka sig att många studenter sannolikt hade valt "i behov av organiserad hjälp" för samtliga heroinbrukare, oberoende av övrig information i vinjetten (Wallander, 2008, 2009). Ett sådant extremvärde på en dimension reducerar således möjligheten att analysera hur övriga dimensioner $\mathrm{i}$ vinjetten påverkar bedömningarna.

${ }^{7}$ När det gäller operationaliseringen av dimensionsnivåerna är det viktigt att beakta validiteten i formuleringarna, dvs. att de mäter det som skall mätas, samt att välja bort formuleringar och uttryck som är svåra eller tvetydiga (jfr Wallander, 2008).

${ }^{8}$ De dimensioner som innehåller endast en nivå är konstanta, dvs. antar samma nivå för samtliga vinjetter. De har inkluderats i form av kontrollvariabler (jfr Wallander, 2008).

${ }^{9}$ Under det här förfarandet kan det bli aktuellt att sålla bort vinjetter som innehåller ologiska kombinationer av vinjettdimensioner (Wallander, 2009).

${ }^{10}$ Ett slumpurval görs enkelt i Excel (jfr Wallander, 2008).

${ }^{11}$ Ett stort tack riktas till PD Dr. Hermann Dülmer, som hjälpte till med att göra Defficiencyurvalet.

12 Vid stora vinjetturval uppvisar även slumpmässiga urval god balans mellan dimensionsnivåerna och approximativ ortogonalitet. Det är främst vid små urval (som i fallet med den aktuella övningen $\mathrm{N}=96$ ), som D-efficiency-urvalet är odisputabelt mest effektivt (Dülmer, 2007).

${ }^{13}$ För mer information om specifika tillvägagångssätt, kontakta artikelns författare.

${ }^{14} \mathrm{Om}$ avsikten är att göra individuella bedömningsprofiler - som är fallet i den aktuella övningen - kan vinjetterna med fördel presenteras i samma ordning för samtliga studenter. Om det däremot skulle finnas ett intresse av att aggregera studenternas bedömningar (i syftet att fånga gemensamma bedömningsprinciper) bör ordningen på presentationen av vinjetterna varieras slumpmässigt mellan studenterna, för att undvika ordningseffekter (eng. "order effects"; jfr Auspurg \& Hinz, 2015).

15 I anslutning till dessa skriftliga instruktioner var det nödvändigt att muntligt klargöra att formuleringen "du bedömer att personen inte har något problem" 
handlade om problem med alkohol eller narkotika, och att termen "organiserad hjälp" handlade om all slags organiserad hjälp för vinjettpersonens alkobol- eller narkotikabruk.

${ }^{16}$ Eftersom den aktuella vinjettdesignen inkluderar dikotoma svarsalternativ, hade multivariat analys inneburit logistisk regressionsanalys. Viktigt att ha $\mathrm{i}$ åtanke är att logistisk regressionsanalys kräver ett relativt högt antal observationsenheter (minst 10 observationer per prediktor; Peduzzi m.fl., 1996) för att resultaten skall vara tillförlitliga, och att det därför hade varit problematiskt att använda den analysformen på våra datamaterial. Om bedömningsövningen däremot hade inkluderat en kontinuerlig svarsskala hade det varit fullt möjligt att göra regressionsanalys, eftersom linjär regressionsanalys inte kräver lika många observationsenheter per prediktor.

${ }^{17}$ Cramér's V är ett korrelationsmått för variabler som befinner sig på nominalnivån och som har fler än två variabelvärden.

${ }^{18}$ Eftersom den aktuella vinjettdesignen innefattar extremt svaga korrelationer mellan vinjettdimensionerna kan vi åtnjuta fördelarna av experimentell kontroll. Detta innebär att vi inte behöver statistisk kontroll (genom multivariat analys), och att de korrelationskoefficienter som vi tar fram kan tolkas i termer av enkla orsakssamband snarare än korrelationer.

${ }^{19}$ En tumregel är att ett Cramér's V-värde under 0,07 indikerar en obetydlig effekt av vinjettdimensionen på bedömningarna.

\section{REFERENSER}

Auspurg, Katrin \& Hinz, Thomas (2015). Factorial survey experiments (Quantitative Applications in the Social Sciences). Thousand Oaks: Sage Publications.

Austin, Michael J. \& Packard, Thomas (2009). Case-based learning: Educating future human service managers. Journal of Teaching in Social Work, (29), 216-236.

Blomqvist, J., \& Wallander, L. (2017). Vad är problemet? Uppfattningar om alkoholens skadeverkningar. Socialvetenskaplig tidskrift, (24), 149-164.

Clark, Michael, D., Determann, Domino, Petrou, Stavros, Moro, Domenico \& de Bekker-Grob, Ester W. (2014). Discrete choice experiments in health economics: A review of the literature. PharmacoEconomics, (32), 883-902.

Cody, Ron (2015). An introduction to SAS® University Edition. Cary: SAS Institute.

Coleman, Marylin, Ganong, Lawrence H., Hans, Jason D., Sharp, Elizabeth A. \& Rothrauff, Tanja C. (2005). Filial obligations in post-divorce stepfamilies. Journal of Divorce \& Remarriage, (43), 1-27.

Cossom, John (1991). Teaching from cases: Education for critical thinking. Journal of Teaching in Social Work, (5), 139-155.

Denk, Charles .E., Benson, John M., Fletcher, John C. \& Reigel, Tina M. (1997). How do Americans want to die? A factorial vignette survey of public attitudes about end-of-life medical decision-making. Social Science Research, (26), 95-120. 
Drummond, Ian, Nixon, Iain \& Wiltshire, John (1998). Personal transferable skills in higher education: The problems of implementing good practice. Quality Assurance in Education, (6), 19-27.

Dülmer, Hermann (2007). Experimental plans in factorial surveys: Random or quota design? Sociological Methods \& Research, (35), 382-409.

Dülmer, Hermann (2016). Design selection and its impact on reliability and internal validity. Sociological Methods \& Research, (45), 304-347.

Ericsson, K. Anders (2006). An introduction to the Cambridge handbook of expertise and expert performance. I K. Anders Ericsson, Neil Charness, Paul J. Feltovich \& Robert R. Hoffman (Red.), The Cambridge Handbook of Expertise and Expert Performance (ss. 3-19). New York: Cambridge University Press.

Green, Paul E., Krieger, Abba M. \& Wind, Yoram Jerry (2001). Thirty years of conjoint analysis: Reflections and prospects. Interfaces, (31), S56-S73.

Herreid, Clyde F. (1997/1998). What makes a good case? Journal of College Science Teaching, (27), 163-165.

Jasso, Guillermina (1988). Whom shall we welcome? Elite judgments of the criteria for the selection of immigrants. American Sociological Review, (53), 919-932.

Jasso, Guillermina (2006). Factorial survey methods for studying beliefs and judgments. Sociological Methods \& Research, (34), 334-423.

Jergeby, Ulla (1999). Att bedöma en social situation: Tillämpning av vinjettmetoden (CUSskrift 1999:3). Stockholm: Centrum för utvärdering av socialt arbete.

Jones, Kim A. (2003). Making the case for the case method in graduate social work education. Journal of Teaching in Social Work, (23), 183-200.

Jones, Kim A. \& Russell, Scott (2008) Using case method teaching and studentwritten cases to improve students' ability to incorporate theory into practice. Journal of Teaching in the Addictions, (6), 35-47.

Lindström, Folke (Red.) (2000). Internmedicin: Problembaserad lärobok med fallbeskrivningar. Lund: Studentlitteratur.

Ludwick, Ruth, Wright, Marion E., Zeller, Richard A., Dowding, Dawn W., Lauder, William \& Winchell, J. (2004). An improved methodology for advancing nursing research: Factorial surveys. Advances in Nursing Science, (27), 224-238.

Lynn, Laurence E., Jr. (1999). Teaching and learning with cases: A guidebook. New York: Chatham House.

Miller, George A. (1956). The magical number seven, plus or minus two: Some limits in our capacity for processing information. Psychological Review, (63), 81-97.

Miller, Joann. L., Rossi, Peter H. \& Simpson, Jon E. (1991). Felony punishments: a factorial survey of perceived justice in criminal sentencing. The Journal of Criminal Law \& Criminology (82), 396-422. 
Milner, Marleen \& Wolfer, Terry (2014). The use of decision cases to foster critical thinking in social work students. Journal of Teaching in Social Work, (34), 269-284.

Nikiforidou, Zoi, Lekka, Aspasia \& Pange, Jenny (2010). Statistical literacy at university level: The current trends. Procedia Social and Behavioral Sciences, (9), 795799.

Onwuegbuzie, Anthony J. \& Wilson, Vicki A. (2003). Statistics anxiety: Nature, etiology, antecedents, effects and treatments - A comprehensive review of the literature. Teaching in Higher Education, (8), 195-209.

Pallant, Julie (2016). SPSS Survival Manual: A Step by Step Guide to Data Analysis Using IBM SPSS (6:e upplagan). Maidenhead: Open University Press, McGraw-Hill Education.

Peduzzi, Peter, Concato, John, Kemper, Elizabeth, Holford, Theodore R. \& Feinstein, Alvan R. (1996). A simulation study of the number of events per variable in logistic regression analysis. Journal of Clinical Epidemiology, (49), 13731379 .

Polanyi, Michael (1966). The tacit dimension. New York: Doubleday \& Company, Inc.

Rossi, Peter H. (1979). Vignette analysis: Uncovering the normative structure of complex judgements. I Robert K. Merton, James S. Coleman \& Peter H. Rossi (Red.), Qualitative and quantitative social research: Papers in honor of Paul F. Lazarsfeld (ss. 176-186). New York: Free Press.

Rossi, Peter H. \& Nock, Stephen L. (1982). Measuring social judgments: The factorial survey approach. Beverly Hills: Sage.

Rossi, Peter H. \& Weber-Burdin, Eleanor (1983). Sexual harassment on the campus. Social Science Research, (12), 131-158.

Samuelsson, Eva, Blomqvist, Jan \& Christophs, Irja (2013). Addiction and recovery: Perceptions among professionals in the Swedish treatment system. Nordic Studies on Alcohol and Drugs, (30), 51-66.

Sauer, Carsten, Auspurg, Katrin, Hinz, Thomas \& Liebig, Stefan (2011). The application of factorial surveys in general population samples: The effects of respondent age and education on response times and response consistency. Survey Research Methods, (5), 89-102.

Short, Robert \& Magaña, Lisa. (2002). Political rhetoric, immigration attitudes, and contemporary prejudice: a Mexican American dilemma. The Journal of Social Psychology, (142), 701-712.

Stiwne, Dan (2009). Från techne till phronesis: Om litteratursamtalets möjligheter i psykoterapeututbildningen. I Torsten Pettersson \& Skans K. Nilsson (Red.), Litteratur som livskunskap: tvärvetenskapliga perspektiv på personlighetsutvecklande läsning (ss. 108-113). Borås: Högskolan i Borås.

Taylor, Brian J. (2006). Factorial surveys: Using vignettes to study professional judgement. British Journal of Social Work, (36), 1187-1207. 
Tornberg, Jakob, \& Wallander, Lisa (2018). Vem är fattig, vem är rik? En faktoriell survey av studenters uppfattningar om fattigdom. Socialvetenskaplig tidskrift, (25), 23-46.

Toulmin, Stephen (1958/2003). The Uses of Argument. Cambridge: Cambridge University Press. Updated edition 2003.

Tärnvik, Arne (2004) Case-metodik - undervisningsform som engagerar: Realistiska övningar ger studenterna chans att träna läkaryrket. Läkartidningen, (101), 33143319.

Wallander, Lisa (2008). Modelling professional judgements: An application of the factorial survey approach to the field of social work. Stockholm: Stockholms universitet.

Wallander, Lisa (2009). 25 years of factorial surveys in sociology: A review. Social Science Research, (38), 505-520.

Wallander, Lisa (2012). Measuring social workers' judgements: Why and how to use the factorial survey approach in the study of professional judgements. Journal of Social Work, (12), 364-384.

Wallander, Lisa, \& Blomqvist, Jan (2005). V ad styr vardvalen? En faktoriell survey av faktorer som predicerar val av insats inom socialtjänstens missbruksvard. FoU-enheten, Stockholm: FoU-rapport 2005:1.

Wallander, Lisa, \& Laanemets, Leili (2017). The factorial survey in mixed methods research: Modelling professionals' individual judgments, SAGE Research Methods Cases Part 2. http://dx.doi.org/10.4135/9781473950146.

Wallander, Lisa, \& Molander, Anders (2014). Disentangling professional discretion: A conceptual and methodological approach. Professions \& Professionalism, (4), 1-19.

Wallander, Lisa, \& Molander, Anders (2016). Learning to reason: The factorial survey as a teaching tool in social work education. Nordic Social Work Research, (6), 234-250.

Webster, Stephen W., O’Toole, Richard, O’Toole, Anita W. \& Lucal, Betsy (2005). Overreporting and underreporting of child abuse: Teachers' use of professional discretion. Child Abuse \& Neglect, (29), 1281-1296. 